\title{
SUJEITO OCULTO: NA ROTA DE GUIMARÃES ROSA (2011) - 26:13
}

Silvio Tendler (direção)

Ana Rosa Tendler (produção)

"Sujeito Oculto: Na Rota do Grande Sertão" é uma jornada pelo norte de Minas Gerias, refazendo o percurso que inspirou cenários e personagens da obra de Guimarães Rosa. Dirigido pelo cineasta Silvio Tendler, diveru elérion das, as veredas, a memória abordando ainda o desastre ecónico que das, as ver a expressões populares. Hoje, aprovado em um edital do Instituto do Patrimôno Histórico Artístico, públicas e exibido nas TVs públicas. públicas e exibido nas TVs públicas. 


\section{D}

Clique na imagem ao

lado para acessar o vídeo

excepcio

(excepcionalmente, hospedado

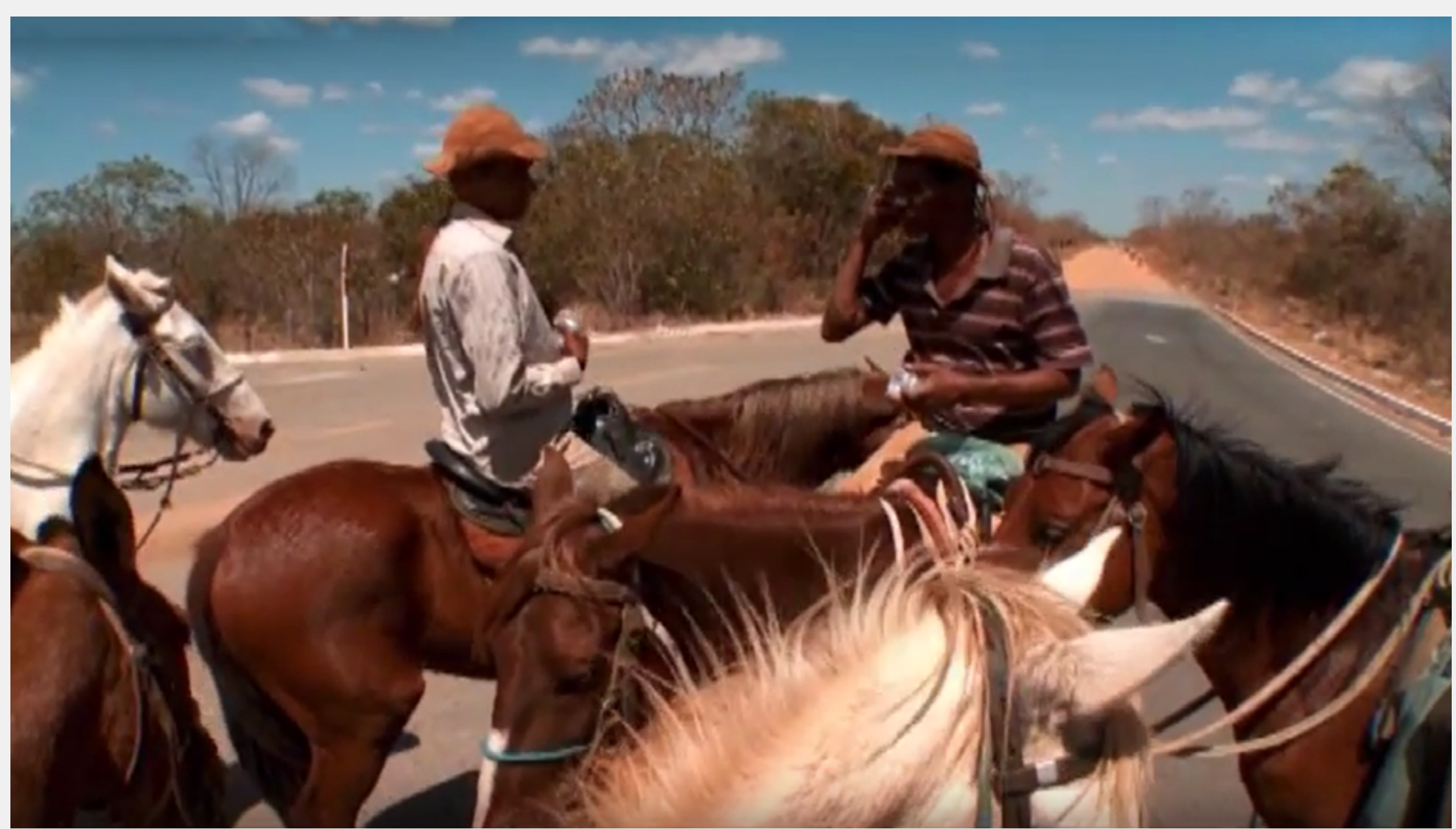

EM TESE

BELO HORIZONTE

v. 22

N. 1

JAN.-ABR. 2016

TENDLER. Sujeito oculto: na rota de Guimarães Rosa

P. 203-204 